\author{
Oksiuta Monika \\ University of Warsaw \\ Faculty of Geography and Regional Studies \\ Department of Hydrology \\ e-mail: m.oksiuta@uw.edu.pl
}

\title{
BASIC PARAMETERS OF THE THERMAL REGIME OF RIVERS IN THE VISTULA RIVER CATCHMENT
}

\begin{abstract}
Seasonal and multi-annual variability of river water temperature has been analysed based on data from 24 gauge stations of the IMGW network. It has been characterised by means of several values of the thermal regime parameters: mean annual, semi-annual (November-April, May-October) and amplitude. The variability of water temperature in the catchment and in the stream network has been estimated. Measurement data included seven stations at the Vistula river. On the background of natural variability, rivers or their segments have been distinguished where water temperature is impacted by anthropopressure.
\end{abstract}

Key words: thermal regime, river water temperature, Vistula river catchment.

\section{INTRODUCTION}

River water temperature is an important characteristic of the environment, but little is known about its variability. Studies conducted in small experimental catchments allowed to determine the dependence of water temperature on air temperature (Calow, Petts, 1994; Mohseni, Stefan, 1999), type of catchment utilisation (Young et al., 2005), substratum lithology (Young et al., 2005), and type of alimentation (Gutry-Korycka, 1967). The author did not compare their results to studies conducted on the scale of a catchment. The results of the first extensive studies of the thermal conditions of Polish rivers were presented many years ago by J. Gołek (1961). Later studies of temperature were mostly of practical character and consisted in the estimation of the impact of heated water from power plants to rivers (Jaworski, 1969; Taboryska, 1987). The influence of a retention reservoir on the formation of the thermal regime of rivers was dealt with by B. Cyberska (1984) and K. Wiejaczka (2006-2007). The construction of the Klimkówka reservoir caused an increase of annual dependence (expressed by the correlation coefficient) in the winter half-year and a decrease in the 
summer half-year (Wiejaczka 2006-2007). Even though the majority of studies dealt with the causes of temperature variability in small flows, it is possible to perform a part of analogous analyses on the scale of the Vistula river catchment (e.g., with respect to flow intensity and conditions for alimentation).

\section{THERMAL REGIME OF THE RIVERS AND MEASUREMENT DATA}

The term "thermal regime of rivers" is practically never encountered in literature, and certainly it is never defined - which causes significant ambiguities. Hydrographic objects are characterised by definite thermal features which change periodically. For this reason it is appropriate to formulate a definition of the notion of "thermal regime" as regards the definition of hydrological regime. The classification of world's river regimes given by M. Pardé (1933) is based on the variability of the annual course of the flow coefficient $k$, which is the ratio of mean monthly and mean annual flow intensities. Analogously, one can determine the thermal coefficient of rivers as the ratio of the mean monthly or seasonal water temperature and the mean annual temperature. A wider definition of the hydrological regime, taking into account the conditions of river alimentation as well as characteristic periods of high- and low-water, is presented by I. Dynowska (1971). In the thermal regime one can talk about the conditions of warming and cooling of river water, and as their measures one can regard the date when the maximum temperature occurs and the date and duration of the occurrence of minimum temperature. The thermal regime of rivers can be defined as the seasonal and multi-annual rhythm of the natural variability of river water temperature parameters, caused by certain definite conditions of water warming and cooling which are related to the thermal resources of rivers. Among the most important thermal regime parameters are annual changes of the thermal coefficient, dates of the occurrence of characteristic temperature values (maximum, minimum, mean), duration of the temperature lower or higher than the characteristic threshold values, as well as the shape of the river water temperature distributions.

Measurements of water temperature are performed with a mercury thermometer (with accuracy $0.1^{\circ} \mathrm{C}$ ) once in 24 hours, at 6 in the morning UTC at the riverside, in the main stream or in another place in the river channel, at the minimum depth of $\approx 0.3 \mathrm{~m}$. In this paper, results of measurements at 24 stations are presented, representing various parts of the Vistula river catchment (Table 1). Water temperature measurements from 27 years (1956-1983) have been used. 


\section{METHODS}

The multi-annual spatial and temporal variability of river water temperature has been determined by means of its annual mean, semi-annual means (for the cold half-year November-July) and the warm half-year MayOctober), and amplitude. These measurements constituted the basis for the estimation of seasonal changes and, together with the remaining parameters, will be essential for the determination of the thermal regime. Because of numerous lacunae in measurements and their low spatial density, it was not possible to perform linear interpolation of point values during the rivers' course.

Discretely-sampled temperature has been presented as a function of the length of flows, on the example of the Vistula river. Due to the localisation of gauge stations it was not possible to assess the impact of non-climate factors (e.g., anthropopressure) such as: mine water inflow or water inflow from industrial plants and power plants.

Table 1. Gauge stations analysed (IMGW Hydrological Yearbooks)

\begin{tabular}{|r|l|l|r|r|r|r|}
\hline No. & River & Gauge station & $\begin{array}{c}\text { Stream } \\
\text { order }\end{array}$ & $\begin{array}{c}\text { Length of } \\
\text { river from } \\
\text { source } \\
{[\mathrm{km}]}\end{array}$ & $\begin{array}{c}\text { Catchment } \\
\text { area } \\
{\left[\mathrm{km}^{2}\right]}\end{array}$ & $\begin{array}{c}\text { Gauge datum } \\
{[\mathrm{m}] \text { n.p.m. }}\end{array}$ \\
\hline 1 & Wisła & Szczucin & 1 & 300.3 & 23900 & 159.15 \\
\hline 2 & Wisła & Sandomierz & 1 & 374.6 & 31846 & 139.14 \\
\hline 3 & Wisła & Puławy & 1 & 478.7 & 57263 & 113.92 \\
\hline 4 & Wisła & Płock & 1 & 738.6 & 169494 & 51.37 \\
\hline 5 & Wisła & Włocławek & 1 & 785.5 & 172389 & 42.17 \\
\hline 6 & Wisła & Toruń & 1 & 840.9 & 181033 & 31.96 \\
\hline 7 & Wisła & Tczew & 1 & 1014.8 & 194376 & -0.58 \\
\hline 8 & Przemsza & Jeleń & 2 & 74.8 & 1995 & 231.10 \\
\hline 9 & Brynica & Szabelnia & 3 & 54.8 & 482 & 244.97 \\
\hline 10 & Dunajec & Krościenko & 2 & 97.9 & 1580 & 413.46 \\
\hline 11 & Dunajec & Nowy Sącz & 2 & 140.3 & 4341 & 275.67 \\
\hline 12 & Dunajec & Żabno & 2 & 229.7 & 6735 & 173.43 \\
\hline 13 & Nida & Pińczów & 2 & 41.0 & 3352 & 183.48 \\
\hline 14 & Wieprz & Krasnystaw & 2 & 105.6 & 3001 & 173.93 \\
\hline 15 & Wieprz & Kośmin & 2 & 285.3 & 10230 & 115.00 \\
\hline 16 & Bug & Frankopol & 3 & 608.8 & 31335 & 109.59 \\
\hline 17 & Bug & Wyszków & 3 & 738.2 & 39119 & 81.47 \\
\hline 18 & Nurzec & Brańsk & 4 & 57.4 & 1226 & 122.25 \\
\hline 19 & Liwiec & Łochów & 4 & 109.2 & 2465 & 96.01 \\
\hline 20 & Wkra & Cieksyn & 2 & 226.5 & 4879 & 76.59 \\
\hline 21 & Bzura & Łowicz & 2 & 110.1 & 3448 & 79.12 \\
\hline 22 & Drwęca & Brodnica & 2 & 122.2 & 3525 & 67.42 \\
\hline 23 & Brda & Tuchola & 2 & 152.1 & 2462 & 87.48 \\
\hline 24 & Wda & Czarna Woda & 2 & 68.2 & 940 & 111.01 \\
\hline & & & & & \\
\hline
\end{tabular}




\section{VARIABILITY AND CHARACTERISTICS OF THE RIVER WATER THERMAL REGIME}

\section{Mean annual water temperature}

Mean annual water temperature in the Vistula river catchment in 19561983 is approx. $9^{\circ} \mathrm{C}$ (Fig.1), with the smallest value $\left(7.4^{\circ} \mathrm{C}\right)$ occurring in the upper Dunajec river (at Krościenko), the gauge station with the highest elevation. The highest mean water temperature $\left(13.8^{\circ} \mathrm{C}\right)$ was recorded in the
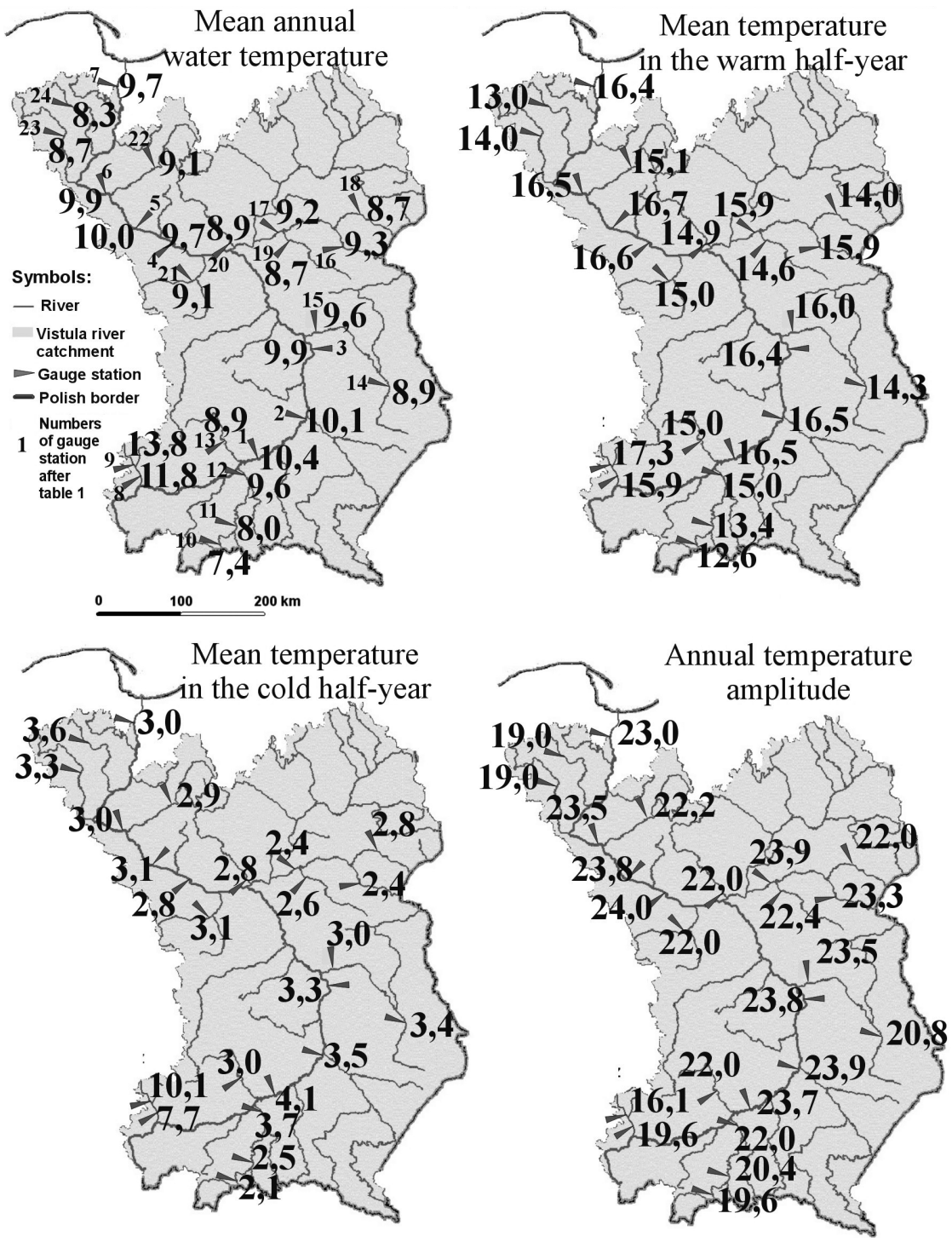

Fig. 1. Selected parameters of running water temperature in the period 1956-1983 
Szabelnia profile on the Brynica river; similar values were recorded on the Przemsza river $\left(11.8^{\circ} \mathrm{C}\right.$, the Jelen profile). The rivers listed represent changed thermal conditions, remaining under the influence of the inflow of heated cooling water from coal-burning power plants and coal mines of Upper Silesia. The difference of the mean annual water temperature in the Vistula river catchment is $6.4^{\circ} \mathrm{C}$. The analogous difference for the lowland rivers is smaller: barely $1.5^{\circ} \mathrm{C}$.

\section{Mean temperature in the warm half-year (May-October)}

Mean multi-annual water temperature in the warm half-year is almost $15^{\circ} \mathrm{C}$, with the smallest value $\left(12.6^{\circ} \mathrm{C}\right)$ observed in the mountain river Dunajec. In the warm half-year many rivers have temperature deviating from the mean value. Cooler water occurs in the $\mathrm{Wda}$ river, due to the lake alimentation. An essential role in the warming process plays the degree of shading of the river channels and valleys cutting through forests (riverside and alder carrs) which restrict the inflow of the direct sun radiation to the open water surface (Wda). The highest multi-annual mean temperature in the warm half-year $\left(17.3^{\circ} \mathrm{C}\right)$ in the Brynica river represents a river loaded with warm water discharge, but the intensity of anthropopressure is small. In the summer half-year water temperature differences in the Vistula river catchment are definitely smaller $\left(4.7^{\circ} \mathrm{C}\right)$ than in the case of the annual mean (Fig. 1).

\section{Mean temperature in the cold half-year (November-April)}

Mean multi-annual water temperature in the cold half-year (NovemberApril) in the Vistula river catchment is only $3.5^{\circ} \mathrm{C}$, but with a distinct impact of anthropopressure. As in the warm half-year, the smallest value in the cold half-year $\left(2.1^{\circ} \mathrm{C}\right)$ was observed in the mountain river Dunajec at Krościenko. In over half of the rivers analysed the water temperature was approx. $3.0^{\circ} \mathrm{C}$ (Fig. 1). The highest mean water temperature in the Brynica river in this half-year was over $10^{\circ} \mathrm{C}$, although in the neighbouring Przemsza river it reached only $7.7^{\circ} \mathrm{C}$, which confirms the impact of the natural alimentation conditions. The force of the thermal pressure of anthropogenic origin in the Upper Silesian Basin is the deciding factor causing the water temperature in the cold half-year to be significantly higher (the Brynica river) or only slightly lower (the Przemsza river) than the annual mean in the multi-year period. The mean difference between the warmest and the coldest water in the catchment in the cold half-year is $8^{\circ} \mathrm{C}$, despite a low variability in winter, when the impact of air temperature below $0^{\circ} \mathrm{C}$ on the formation of ice cover as a result of phase transitions of water is distinctly marked.

\section{Annual temperature amplitude}

Annual river water temperature amplitude in the multi-year period in the catchment studied is $21^{\circ} \mathrm{C}$. The lowest daily water temperature in most rivers varies between 0.0 to $0.2^{\circ} \mathrm{C}$, thus the yearly amplitude is determined by the maximum yearly water temperature (except for watercourses under 
anthropopressure, where the relationship is the opposite). The lowest yearly temperature amplitude $\left(16.1^{\circ} \mathrm{C}\right)$ is in the Brynica river, slightly higher, in the Przemsza $\left(18.8^{\circ} \mathrm{C}\right)$, Brda $\left(19.0^{\circ} \mathrm{C}\right)$ and $\mathrm{Wda}\left(19.0^{\circ} \mathrm{C}\right)$ rivers (Fig. 1), which results from the lake alimentation. The highest mean water temperature amplitude $\left(24.0^{\circ} \mathrm{C}\right)$ in the Vistula river was observed in Płock, and similarly in the Bug river in Wyszków. The maximum yearly water temperature amplitude $\left(29.6^{\circ} \mathrm{C}\right)$ was observed in the Liwiec river in 1956.
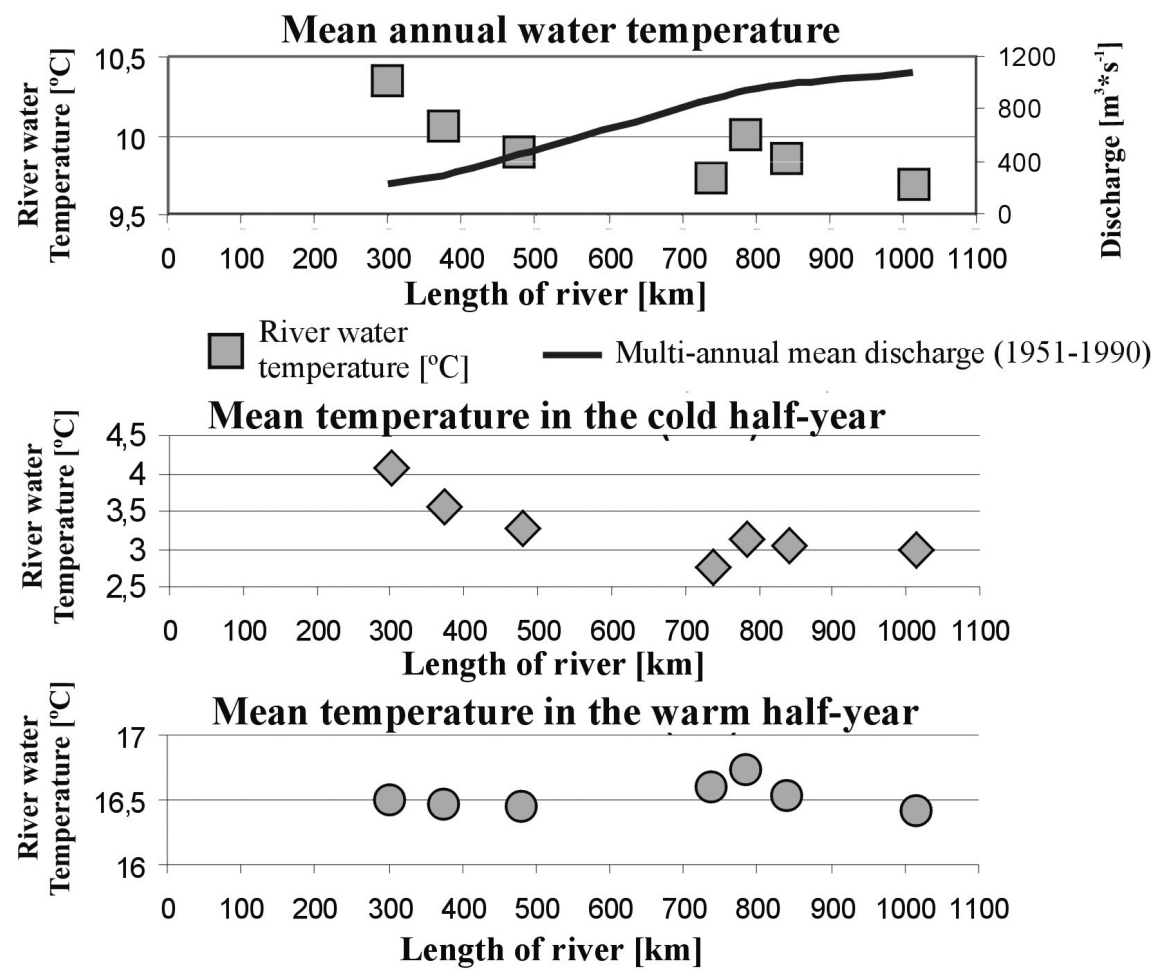

Fig. 2. Water temperature changes along the Vistula river course

The analysis of the water temperature changes along the river course has been performed only for the Vistula river, due to insufficient density of the measurement network. The mean annual water temperature in the upper Vistula river is the highest (Fig. 2). The Vistula river waters at Szczucin and Sandomierz were within the impact area of the heated sewage inflow from GOP, Kraków, and Sandomierz. Only a small decrease of the mean annual water temperature occurs along the course of the Vistula river. This system is disturbed by the Włocławek Reservoir, which causes an increase of the mean annual temperature by $0.3^{\circ} \mathrm{C}$. In the warm half-year the annual temperature does not exhibit changes along the river course. Also below the dam at Włocławek the water is only slightly warmed. The largest 
changes of water temperature $\left(>1^{\circ} \mathrm{C}\right)$ along the river course increases occur in the cold half-year. In this period, similarly as during the entire year, an increase of the annual water temperature along the water course is observed, except for a slight increase below the Włocławek Reservoir. The changes of the Vistula river thermal conditions exhibited a decreasing tendency or slight stability, which is a result of a considerable thermal inertia of the river and the changes in the flow magnitude.

\section{CONCLUSIONS}

The variability of the river water temperature in the 27 years analysed (1956-1983) in not large in absolute values. Taking into account, however, the considerable thermal capacity of water and its thermal inertia, the spatial differentiation of temperature which equals only $1-2^{\circ} \mathrm{C}$, can be regarded as clearly marked; the more so that thermal control encompasses the largest rivers, that is, rivers with large thermal capacity. The water temperature variability obtained is close to the results of J. Gołek (1961), obtained on the basis of shorter (approx. 10 years) measurement data until 1956. Water is definitely cooler in mountain and lakeland rivers, while it is warmest in lowland and Upper Silesia rivers where the anthropogenic impact is clearly marked. Regional features are less essential factor shaping thermal regime. The lack of at least 3 measurement points on the same river limits the possibility of water temperature change analysis along the river course. Such an analysis is possible only in the case of the Vistula river (7 measurement points), although water temperature changes as a function of the river length are small.

\section{REFERENCES}

Calow P., Petts G. E., 1994, The river handbook. Volume 1, Blackwell Scientific Publications, Oxford.

Cyberska B., 1984, Oddziaływanie zbiorników retencyjnych na reżim termiczny rzek [Interaction of retention reservoir on thermal regime of rivers], Czasopismo Geograficzne, LV, 3, 345-354.

Dynowska I, 1971, Typy reżimów rzecznych $w$ Polsce [Types of river regimes in Poland], Prace Inst.Geogr. UJ, 50.

Gołek J., 1961, Termika rzek polskich [Temperature of Polish rivers], Prace Państwowego Instytutu Hydrologiczno-Meteorologicznego, 62, Wydawnictwa Komunikacji i Łączności, Warszawa.

Gutry-Korycka M., 1967, Temperatura potoków tatrzańskich o różnych źródłach zasilania [Temperature of Tatra Mountain,s Creek with different sources of inflow]. Przeg. Geograf. XXXIX, 3, 577-584.

Jaworski J., 1969, Zmiany bilansu cieplnego wód spowodowane wptywem zrzutów podgrzanych wód przemystowych [Changes of water heat balance cause influence industrial hot water inflow], typescript, IMGW, Warszawa.

Mohseni O., Stefan H. G., 1999, Stream temperature/air temperature relationship: a physical interpretation, Journal of Hydrology 218, 128-141.

Pardé M., 1933, Fleuves et Rivières, Armand Colin, Paris. 
Taboryska B., 1987, Ocena wptywu zrzutów podgrzanych wód pochłodniczych z Elektrowni Stalowa Wola na chemizm i biocenoze Sanu [Estimate of influence heated water inflow from Stalowa Wola power plants on chemistry and biological life of San river], typescript, IMGW, Warszawa.

Young R. G., Eyles R. F., Smith R. A., Bowden W. B., 2005, Water quality and termal regime of the Mouteka River: influences of land cover, geology and position in the catchment, New Zeland Journal of Marine and Freshwater Research, vol. 39, 803-825.

Wiejaczka Ł., 2006-2007, Relacje pomiędzy temperatura wody w rzece a temperatura powietrza (na przykładzie rzeki Ropy) [Relations beetwen river water temperature and air temperature (for example Ropa riverver)], Folia Geographica, Series GeographicaPhysica, vol. XXXVII-XXXVIII, 95-105.

English translation: Małgorzata Mikulska 